\title{
A SOCIAL MEDIA FRAMEWORK OF CULTURAL MUSEUMS
}

\author{
Gökçe ÖZDEMİR ${ }^{1}$ \\ Department of Tourism Management, Yaşar University, İmir, Turkey \\ Duygu ÇELEBİ \\ Department of Tourism Management, Yaşar University, İzmir, Turkey
}

\begin{abstract}
Museums are regarded as cultural products and the core attractions of a destination that offer cultural, historical and artistic possessions for locals as well as tourists. Technological developments in communication have also contributed to the museum pre-, onsite and postexperience of visitors. Thereby, social media enables the museums to extend their networks also on an international basis with up-to-date and credible information about current researches, special events, new exhibitions, excavations in process, and promotional activities. In this sense, this study demonstrates how social media is used by
\end{abstract}

\section{Article History}

Received 30 May 2017

Revised 03 October 2017

Accepted 10 October 2017

\section{Keywords}

Culture

Museum

Social media

\footnotetext{
${ }^{1}$ Address correspondence to Gökçe Özdemir (PhD), Department of Tourism Management, Yaşar University, İzmir, TURKEY. E-mail: gokce.ozdemir@yasar.edu.tr
} 


\section{INTRODUCTION}

Today, culture has become a key factor in the competition among cities to attract visitors, and an important part of the service-based economy (Porter, 1998). As being an arks of culture (Panero, 2012), the well-known meaning of museums refers to non-profit organizations within the service sector that create a unique bond among nations' own cultural heritage and modern life (Kirezli, 2011). From a similar angle, Hume and Mills (2011) specified the museums as non-profit organizations and remark museums' obligation for the public good as collection, conservation and education. Similarly, McLean (1995) focuses on the responsibility of museums as preserving and conserving the museum related collection in its care. Therefore, museums are defined as major attractions that disseminate the culture and history of the society, as well as the fine arts including painting, sculpture, film, photography, music, poetry and architecture associated with the region.

Museums are unique, information oriented organizations aimed towards educating but also providing logical connection between past and current topics such as political, social, cultural and environmental (Yeh \& Lin, 2005). Museums also enable visitors to both interact and communicate with museum related facilities in order to know and establish past and present within a given architectural space (Jeong \& Lee, 2006). In fact, museums are centers of knowledge, and the mission to offer an educational experience is the key objective in serving visitors (Waltl, 2006). McLean (1995) also mentioned both educational and entertainment related features of museums, and pointed out that these ingredients are inseparable from each other in terms of consumption of the museum service.

Today, museum managers struggle with the issues of maintaining their museum's integrity as a distinctive collecting, conserving, research, exhibiting and educational institution, and at the same time, making their museum more popular and competitive (Kotler \& Kotler, 2000). Considerably, museum managers are striving hard to improve their offering and experience to be far from boring and static process but to encourage museum visitation. Bollo and Dal Pozzolo (2005) indicate that museum experience includes; the time, the choice of display area, the attention span and the ability of the information to hold the attention of the user, and the way the visit is organized. In fact, as a part of an evolving, interconnected cultural life, museums encourage discovery of culture as a whole fabric, in its variety of manifestations (Kotler, 2001). 
Therefore, museums reflecting culture, history and/or art are the main attractions of a destination in terms of cultural tourism that provides prehistoric, folkloric and aesthetic assets for tourists. In addition, museums not only attract tourists but also serve as a leisure activity place for locals.

Cultural and art museums assist the dissemination of history and culture to the visitors through archeological objects, paintings, sculptures with various stories in terms of modern or classic art, culture and history. Besides, other types of museums such as wax museum, sex museum, toy museum or science museum all have their own aim to serve to the specific target markets. For instance, science museums offer theoretical and practical learning opportunities related to science while others also focus on the theme their name implies. The study of Stylianou-Lambert (2011) reveals that (a) tourists who visit art museums differ from tourists who visit other cultural activities and other kinds of museums, and (b) that cultural tourism is an extension of everyday life. However, museums like every other thing are evolving from physical to virtual environments. With a broad vision and different perspective, Badalotti, De Biase and Greenaway (2011) foresee the future museum to be multi-located, scalable at the European or international level, offered to public spaces, physical and virtual, open to multiple experiences and providing points of interaction with different and wider communities.

According to Cole (2008), there are two major forces leading museum practitioners to proactively engage with marketing activity. Today, one major force is the need to generate the necessary visitation figures to either justify government funding and/or simply to remain financially feasible. Another major force is the desire to become more people-oriented, to place public service at the core of the educative duty. In this sense, marketing and promotion plays a crucial role in the survival of museums in terms of governmental or donator support, and increase in local, national and international visits. In addition, established relationships among museums and visitors, volunteers and donors leads to ultimate success of museums and open the path for their survival (Fletcher \& Lee, 2012). This study demonstrates how social media should be used by the museums by focusing on the social media presence of leading and well-known international cultural museums. In this regard, content analysis as a qualitative research method is used to build up a framework of categories that would be useful for practitioners in the museum marketing field. 


\section{LITERATURE REVIEW}

\section{Enhancement of Experiences in Museums through Technology}

Internet has opened up a completely new way of engaging users' experiences that encourage discovery, interaction, cater for the unexpected, provide many pathways to explore, give a taste for what happens behind-the-scenes and are fun (Kelly, 2008). In this sense, museums are expected to shift their traditional identity with the modern approach by providing interactive learning environments for visitors (Yeh $\&$ Lin, 2005). Accordingly, private or public museums attempt to develop continuous relationship with the existing or prospective customers through new and effective communication tools. According to Styliani, Kostas and Petros (2009), extension of internet usage has made the content and context of museum collections more accessible and attractive to the public and thus has enriched the museum experience. Thereby, Kaplan and Haenlein (2010) define social media as a group of Internet based applications which build on the ideological and technological foundations of Web 2.0, allowing creation and exchange of user generated content. Today, museums are devoted to engage in digital media opportunities in order to enable greater visitation through cost-effective communication. Hence, it's proved that creating a strong online presence in social media sites now boosts more interest relative to traditional media. As Kelly (2008) implies, the majority of people who visit museums are collegeeducated or higher which implies that the visitors of museums are most likely familiar with the latest technology usage.

Amato et al. (2013) points out that in order to improve the visitor's experience in museums through multimedia solutions, many museums and cultural heritage sites have adopted several systems and technologies. In the last few decades, museums have started to integrate their programs with interactivity both for learning and entertainment purposes through technological developments applicable to museums. The introduction and development of multimedia information systems have also revolutionized the traditional structure and common marketing efforts of museums on a vast scale by concerning a worldwide network of potential museum visitors through web and social media usage (Padilla-Meléndez \& del Aguila Obra, 2013).

Mancini and Carreras (2010) indicate that Web 2.0 offers online museum activities with two strategic opportunities: cultural and commercial. According to the authors, to create a dialogue with the audience via information exchange, improving the cultural level, 
increasing awareness of art and encouraging participation in cultural debates is regarded as a cultural opportunity. To increase promotion, advertising and revenues through e-commerce, merchandizing and visits are regarded as commercial opportunities of museums. Thus, creating both an invaluable physical and a virtual museum experience requires high concentration of new technology. With the existence of online technology, museums expand their services by allowing the consumers to visit the official website of museum, comparing the exhibitions and embracing the history and artifacts together in an online way (Hume \& Mills, 2011). By this means, Marty (2007) points out that visitors of physical museums should feel similarly inspired to visit the museum's website, using the website as a bridge to connect their pre-visit and postvisit activities by learning more about the museum and its collections.

\section{Museums in Social Media}

In a general sense, social media provides new channels for the production and circulation of meaning in tourism experiences and imaginations (Munar \& Jacobsen, 2014). However, it is critical to understand consumer behavior depending on changes of new information technologies, because social media marketing is playing an increasingly important role in hospitality and tourism field (Chan \& Guillet, 2011; Xiang \& Gretzel, 2010). Additionally, according to Marty (2007), museums can achieve innovative solutions to complex problems by using social media as a platform and museums as a laboratory for extending partnership and building capacity by creatively connecting design communities. Recently, social media has become the method of statement in the $21^{\text {st }}$ century, enabling people to express their beliefs, ideas, and manner in an absolute new way (Saravanakumar \& Suganthalakshmi, 2012). Thus, Hausmann (2012) emphasizes the significance of WOM as a special method to reach ultimate number of visitors by using social media channels.

Undoubtedly, presence of museums in social media is highly essential but it must be remembered that choosing an effective and appropriate social media channel is relatively important too. Social media offers various types of channels namely; Facebook, Twitter, Pinterest, Instagram and blogs with different functions, fields of activity and purpose. As Russo (2011) stresses, social networks like Twitter for instance helps to promote brand recognition and build brand loyalty. In addition to this, Saravanakumar and Suganthalakshmi (2012) underlined the Twitter's features as an easy, quick and time efficient platform that leads to increase 
of customer insight, sales and buzz. On the other hand, Instagram is known as another crucial platform of social media that communicates the untold experiences through visual materials (Weilenmann, Hillman, \& Jungselius, 2013). Blogs are very different from other social media channels with its function that is managed by only one person but they provide interaction with others through the addition of comments (Kaplan \& Haenlein, 2010). Lastly, Facebook is the most preferred social media channel within the globe. According to Saravanakumar and Suganthalakshmi (2012), Facebook allows marketers to establish and enhance the brand image, and authority of company within the competitive market.

Yet, there are now museums that have started to experiment with social media in order to attract visitors and encourage users to connect with cultural institutions (Mancini \& Carreras, 2010). For instance, Pett (2012) takes the attention to British Museum's aim to be "A museum of the world for the world", which has also become increasingly important to engage with an online audience that may not be able to physically visit with the museum. According to Russo, Watkins, Kelly and Chan (2008), blogs, podcasts and content shares are currently used as an effective social media tool by major museums to engage users via participatory communication between museums and users. In the light of these, the new term "social museology" has emerged eventually with the effective integration of social media technologies and the museums (Karagöl, 2014).

In this sense, creating informative, encouraging and appealing social media accounts seems to be a pathway to museum experiences in addition to well-designed functional websites. Therefore, social media does not only assist in attracting new visitors but also creates repeat visitation through promoting new exhibitions, introducing new artifacts, announcing news or seminars that arouse curiosity and stimulate demand. Since museum without visitors is like lifeless and empty halls with no purpose (Waltl, 2006), social media should be used as an effective medium to publicize information, build awareness and generate more visits.

Thanks to technology, every offering is more accessible than ever by the transformed communication tools and it is a fact that, social media has reformed the marketing concept with the ease of communication process. Thus, Scott and Orlikowski (2012) remark the rise of social media and user-generated content to create a powerful combination for transparency and accountability. Chan and Guillet (2011) also refer that social media should not be considered only as an online distribution 
channel but also as an effective tool to perform service recovery, develop relationship with customers, and build brand loyalty within the community. Yet, social media exist in a variety of forms and serve numerous purposes (Xiang \& Gretzel, 2010) with the utmost purpose of promoting people, ideas, places, services and goods. Therefore, social media account of a museum should not only appeal online visitors with the information it provides, but also encourage them to visit the museum in person.

Zeng and Gerritsen (2014) declare that social media sites are also recognized as an important information source for the travelers to arrange their plans. Additionally, using social networking sites strengthen the bond with the audience through its active presence by providing information, addressing questions, and responding to comments (Hsu, 2012). Besides, Zhou and Wang (2014) acknowledge social media as having a participative, interactive, open and transparent nature. This nature also assures constant interest of the visitors, and enhances the visitor knowledge beforehand to reduce risks of an experiential museum product for the first time visitors.

According to Dindler and Iversen (2009), museum engagement is a situational phenomenon that occurs in the interplay between visitors and the exhibition space, but it is also very much rooted in the visitors' prior experiences, knowledge and preferences. In this regard, provision of information about museums through official social media accounts is possible through pictorial and textual material. Museums' managers are becoming more conscious about the opportunities generated by the social media and buzz marketing in order to maximize the interest of the visitors. Kierzkowski, McQuade, Waitman and Zeisser (1996) also mention that with the consumers being engaged, the next step is to retain the visitors. Thereby, social media as an online channel enables interaction between parties; sharing of stories or information about the exhibits, assets and upcoming events; publishing relative photos, audio and video; and receiving simultaneous response from the audience.

Mancini and Carreras (2010) points out that social media have the potential to transform the museum visitor into an active participant involved in the creation of knowledge. To create a credence, promotional online content must be as specific and informative as possible and should include customer-generated information as well as firm-generated information (Sparks, Perkins, \& Buckley, 2013). So from the museums' point of view, social media also enables interaction among members that 
are interested in museums and associated information. Therefore online communication through social media should create the opportunity to share photos and videos, make comments and express opinions that possibly arouses curiosity about the museum. Nevertheless, social media allows visitors to pre-taste museum experience through posts as well as enables the museums to extend their networks internationally with spreading up-to-date and credible content about new researches, special events new exhibitions and/or new excavations, and promotional activities.

\section{METHODOLOGY}

The aim of this study is to create a broad framework depending on the content of social media accounts of cultural museums and to analyze their performance. Thus, the researchers examine worldwide well-known museums and galleries' social media usage performance, as gallery is often used interchangeably with museum as in the case of Ufizzi Gallery. Those museums' social media accounts are evaluated to create a framework and an ideal blend of content for the effective use of social media. This is being done through qualitative content analysis. Content analysis that is widely used in terms of qualitative research involves the systematic categorization of explicit or implicit data. Following the qualitative content analysis process, categories are carefully detected and derived from written textual information on Facebook accounts. Thereby, posts on the Facebook accounts were examined one by one, categorized accordingly and the underlying context is interpreted.

The research is conducted in February 2015 by visiting the accounts of selected museums on Facebook. Facebook is one of the leading social networks all around the globe, so the research on museums' performance is based on official Facebook accounts. In fact, Facebook is not only used by individuals, but is also used as a marketing tool for institutions or establishments. The authors limited the research to 10 museums due to their worldwide known distinctiveness also determined in the book of The 10 Best of Everything published by National Geographic Press. These famous museums are respectively listed as; Smithsonian Institution, Washington, D.C.; Le Louvre, Paris, France; The Acropolis Museum, Athens, Greece; State Hermitage, St. Petersburg, Russia; The British Museum, London, England; The Prado, Madrid, Spain; The Metropolitan Museum of Art, New York City, New York; The Vatican Museums, Vatican City, Italy; The Uffizi Gallery, Florence, Italy; Rijksmuseum, 
Amsterdam, the Netherlands. On the other hand, The Smithsonian Institution is relatively different from other museums in the list that can be referred as the world's largest museum and content-rich complex containing 19 museums, galleries and the National Zoological Park within it. Thereby, although 10 museums' social media accounts are subject to research, totally 28 museums are included in the study as Smithsonian Museum represents 19 museums and galleries. However, the research is limited to posts of 2014, as the museums' Facebook accounts have significant number of posts since they have started to function.

According to Newsroom of the Smithsonian, number of the museums and the National Zoo visitations has reached more than 28 million visits in 2014. One should keep in mind that the Smithsonian Institution includes not only one museum but also different varieties of museums and galleries. Therefore, this capacity can explain the reason behind the high amount of visitations. According to the special report about top 100 art museum attendances in all around the world in The Art Newspaper International; La Louvre Museum has gained the 'most visited museum' reputation with the number of 9,260,000 visitors. The British Museum and The Metropolitan Museum have followed this reputation with their same visitor numbers that reach more than six million. In addition, the Vatican Museum has reached to 5,891,332 visitors in 2014. Respectively, State Hermitage Museum, The Prado Museum, Rijksmuseum, The Uffizi Gallery and The Acropolis Museum recorded less number of visitors than the other museums on the list.

Table 1. Numbers of Museum Visitors in 2014

\begin{tabular}{lc}
\hline Museums & Visitation Numbers in 2014 \\
\hline Smithsonian Institution & $+28,000,000$ \\
Le Louvre Museum & $9,260,000$ \\
The British Museum & $6,695,213$ \\
The Metropolitan Museum & $6,162,147$ \\
The Vatican Museum & $5,891,332$ \\
State Hermitage Museum & $3,247,956$ \\
The Prado Museum & $2,536,844$ \\
Rijksmuseum & $2,450,000$ \\
The Uffizi Gallery & $1,935,901$ \\
The Acropolis Museum & $1,377,405$ \\
\hline
\end{tabular}

The methodological research process of the study comprises of two stages. In the first stage, each Facebook account of the museums is visited by one author in order to create an outline of contents based on the objectives of the study. Therefore, each post with its content is analyzed to 
construct a category framework and finally 32 categories were determined. In the second stage, each post is re-checked by the other author to agree and assure which category the posts belong to. Consequently, the posts in the Facebook accounts are double-checked that enables the research to be more dependable in its own sense. These structured categories of the content are explained with the research findings and presented in the final stage.

\section{FINDINGS AND DISCUSSION}

Facebook accounts of the museums, subjects in this study, are content analyzed one by one by the authors of this paper first separately and then the results were compared to avoid any misrepresentation. The results of the content analysis are reported in this section in detail with tables. According to the starting dates of official Facebook accounts, Smithsonian Institution, The Metropolitan Museum and The Vatican Museum are the oldest ones which have been in operation since 2008 and used efficiently to connect to audience ever since. For instance, State Hermitage Museum has started its presence on Facebook only in 2013. The number of followers for each account is also checked by the researchers and presented in Table 2 as it is an important indicator of marketing communication power. Therefore it is found that Le Louvre Museum is at the first place in terms of number of followers with 1,672,236 followers; and The Ufizzi Gallery with 9.302 followers has the least number of followers among all museums in the list. Moreover, as language support of the Facebook accounts is one of the significant factors that make the information accessible, availability of language support is also identified. Providing information in many languages is an indicator of being global and also enables museums to expand its limits of reach. Originally, Smithsonian Institution, The British Museum, The Metropolitan Museum share all their posts in English as well as The Vatican Museum. Conversely, Le Louvre Museum, State Hermitage Museum, The Prado Museum, The Uffizi Gallery, and Rijksmuseum share their posts in their own native language and Facebook offers translation options for the followers. On the other hand, the Acropolis Museum's some posts could not be translated and they were indicated as "N/A" in Table 3, implying the question mark about the existence of the category in the relevant Facebook account. 
Table 2. General Framework for Official Facebook Accounts (2014)

\begin{tabular}{lccc}
\hline Museums & $\begin{array}{c}\text { Starting Date of } \\
\text { Account }\end{array}$ & $\begin{array}{c}\text { Number of } \\
\text { followers }\end{array}$ & $\begin{array}{c}\text { Language } \\
\text { Support }\end{array}$ \\
\hline Smithsonian Institution & 2008 & 349,888 & English \\
Le Louvre Museum & 2009 & $1,672,236$ & French \\
The Acropolis Museum & 2009 & 434,546 & Greek \\
State Hermitage Museum & 2013 & 15,324 & Russian \\
The British Museum & 2009 & 689,964 & English \\
The Prado Museum & 2009 & 430,554 & Spanish \\
The Metropolitan Museum & 2008 & $1,305,862$ & English \\
The Vatican Museum & 2008 & 73,154 & English \\
The Uffizi Gallery & 2012 & 9,352 & Italian \\
Rijksmuseum & 2009 & 19,536 & Dutch \\
\hline
\end{tabular}

The framework of communication content of museums on Facebook through their official accounts is constructed of 32 categories detected as listed in Table 3.

Contact information is an essential category, which enables followers to reach more detailed information about museums such as how to get there, google map, link to the official website, closing/opening hours of museums in addition to the address, e-mail address, phone and fax number.

Integration of other social media tools is the backbone of museums within the scope of technology based communication. Analysis of the results shows that, all museums engage their Facebook posts correspondingly with other social media platforms such as; Blogs, Instagram, Twitter, Pinterest and You Tube.

Engagement of important dates with posts is another category that includes agenda, anniversary, celebration, ceremony concerned posts such as; New Year, Christmas, Election Day, Valentine's Day, Festivals, Special Days and so on through special slogans, videos and hashtags, photographs and/or related art objects. This category existing in museums' official Facebook accounts assists museums to maintain the followers' interest and to keep the account alive and eye-catching like Smithsonian Institution, State Hermitage Museum, The British Museum, The Prado Museum, The Metropolitan Museum, The Vatican Museum, The Uffizi Gallery and Rijksmuseum do. 
Table 3. Social Media Usage Framework for Official Facebook Accounts (2014)

\begin{tabular}{|c|c|c|c|c|c|c|c|c|c|c|}
\hline Categories & $\begin{array}{l}\text { Smithsonian } \\
\text { Institution }\end{array}$ & $\begin{array}{c}\text { Le } \\
\text { Louvre } \\
\text { Museum }\end{array}$ & $\begin{array}{c}\text { The } \\
\text { Acropolis } \\
\text { Museum }\end{array}$ & $\begin{array}{c}\text { State } \\
\text { Hermitage } \\
\text { Museum }\end{array}$ & $\begin{array}{c}\text { The } \\
\text { British } \\
\text { Museum }\end{array}$ & $\begin{array}{c}\text { The } \\
\text { Prado } \\
\text { Museum }\end{array}$ & $\begin{array}{c}\text { The } \\
\text { Metropolitan } \\
\text { Museum }\end{array}$ & $\begin{array}{c}\text { The } \\
\text { Vatican } \\
\text { Museum }\end{array}$ & $\begin{array}{l}\text { The } \\
\text { Uffizi } \\
\text { Gallery }\end{array}$ & Rijksmuseum \\
\hline 1. Contact information & $\checkmark$ & $\checkmark$ & $\checkmark$ & $\checkmark$ & $\checkmark$ & $\checkmark$ & $\checkmark$ & $\checkmark$ & $\checkmark$ & $\checkmark$ \\
\hline 2. Integration of other social media tools & $\checkmark$ & $\checkmark$ & $\checkmark$ & $\checkmark$ & $\checkmark$ & $\checkmark$ & $\checkmark$ & $\checkmark$ & $\checkmark$ & $\checkmark$ \\
\hline 3. Engagement of important dates with posts & $\checkmark$ & & N/A & $\checkmark$ & $\checkmark$ & $\checkmark$ & $\checkmark$ & $\checkmark$ & $\checkmark$ & $\checkmark$ \\
\hline 4. Information about museum employees & $\checkmark$ & & N/A & $\checkmark$ & $\checkmark$ & $\checkmark$ & $\checkmark$ & & $\checkmark$ & $\checkmark$ \\
\hline 5. Detailed Information about artifacts- collections & $\checkmark$ & $\checkmark$ & N/A & $\checkmark$ & $\checkmark$ & $\checkmark$ & $\checkmark$ & & $\checkmark$ & $\checkmark$ \\
\hline 6. Slogan & $\checkmark$ & & N/A & & $\checkmark$ & & & & & \\
\hline 7. Hashtag & $\checkmark$ & $\checkmark$ & & $\checkmark$ & $\checkmark$ & & $\checkmark$ & & $\checkmark$ & $\checkmark$ \\
\hline 8. Installation process of exhibitions & $\checkmark$ & $\checkmark$ & N/A & $\checkmark$ & $\checkmark$ & $\checkmark$ & $\checkmark$ & & & $\checkmark$ \\
\hline 9. Additional links & $\checkmark$ & $\checkmark$ & $\checkmark$ & $\checkmark$ & $\checkmark$ & $\checkmark$ & $\checkmark$ & $\checkmark$ & $\checkmark$ & $\checkmark$ \\
\hline 10. Researches, reports and projects & $\checkmark$ & & N/A & $\checkmark$ & $\checkmark$ & $\checkmark$ & & & $\checkmark$ & $\checkmark$ \\
\hline 11. Announcements & $\checkmark$ & $\checkmark$ & N/A & $\checkmark$ & $\checkmark$ & $\checkmark$ & $\checkmark$ & $\checkmark$ & $\checkmark$ & $\checkmark$ \\
\hline 12. Digital offers & $\checkmark$ & $\checkmark$ & N/A & & $\checkmark$ & $\checkmark$ & $\checkmark$ & & $\checkmark$ & $\checkmark$ \\
\hline 13. Updates about museum & $\checkmark$ & $\checkmark$ & N/A & $\checkmark$ & & & & $\checkmark$ & $\checkmark$ & \\
\hline 14. Posts of videos/broadcasts & $\checkmark$ & $\checkmark$ & $\checkmark$ & $\checkmark$ & $\checkmark$ & $\checkmark$ & $\checkmark$ & $\checkmark$ & $\checkmark$ & $\checkmark$ \\
\hline 15. Posts of photographs & $\checkmark$ & $\checkmark$ & $\checkmark$ & $\checkmark$ & $\checkmark$ & $\checkmark$ & $\checkmark$ & $\checkmark$ & $\checkmark$ & $\checkmark$ \\
\hline 16. Posts of audio & & $\checkmark$ & N/A & & & & & & $\checkmark$ & \\
\hline 17. Posts of online games & & $\checkmark$ & & & & & & & & \\
\hline 18. Tips/suggestions & $\checkmark$ & & N/A & & & & & & $\checkmark$ & $\checkmark$ \\
\hline 19. "Did you know that" & $\checkmark$ & $\checkmark$ & N/A & & $\checkmark$ & & $\checkmark$ & & & $\checkmark$ \\
\hline 20. Invitations & & $\checkmark$ & $\checkmark$ & $\checkmark$ & $\checkmark$ & $\checkmark$ & $\checkmark$ & & & $\checkmark$ \\
\hline 21. Educational posts & $\checkmark$ & $\checkmark$ & N/A & & $\checkmark$ & $\checkmark$ & $\checkmark$ & & $\checkmark$ & $\checkmark$ \\
\hline 22. Suggestions/opinions of followers & $\checkmark$ & $\checkmark$ & N/A & & & & & & & \\
\hline 23. Interactive talk & & $\checkmark$ & N/A & & & & & & & \\
\hline 24. Daily routine messages & & $\checkmark$ & N/A & & & & & & $\checkmark$ & \\
\hline 25. Info about museums multimedia devices & & $\checkmark$ & N/A & & & & & & $\checkmark$ & \\
\hline 26. Info about souvenirs in the Museum Shop & & & $\checkmark$ & & $\checkmark$ & & & & & $\checkmark$ \\
\hline 27. Booking opportunities via account & & & & & $\checkmark$ & $\checkmark$ & & $\checkmark$ & $\checkmark$ & $\checkmark$ \\
\hline 28. Engagement to current exhibitions & $\checkmark$ & $\checkmark$ & & $\checkmark$ & $\checkmark$ & $\checkmark$ & & $\checkmark$ & & $\checkmark$ \\
\hline 29. Info about other facilities of museums & & & N/A & & $\checkmark$ & & & & & \\
\hline 30. Info about facilities for disabled visitors & & & N/A & & & $\checkmark$ & & & $\checkmark$ & \\
\hline 31. Donation opportunities & & & N/A & & & & $\checkmark$ & & $\checkmark$ & \\
\hline 32. Competitions & & & N/A & & & & & & & $\checkmark$ \\
\hline
\end{tabular}


Contact information is an essential category, which enables followers to reach more detailed information about museums such as how to get there, Google map, link to the official website, closing/opening hours of museums in addition to the address, e-mail address, phone and fax number.

Integration of other social media tools is the backbone of museums within the scope of technology based communication. Analysis of the results shows that, all museums engage their Facebook posts correspondingly with other social media platforms such as; Blogs, Instagram, Twitter, Pinterest and You Tube.

Engagement of important dates with posts is another category that includes agenda, anniversary, celebration, ceremony concerned posts such as; New Year, Christmas, Election Day, Valentine's Day, Festivals, Special Days and so on through special slogans, videos and hashtags, photographs and/or related art objects. This category existing in museums' official Facebook accounts assists museums to maintain the followers' interest and to keep the account alive and eye-catching like Smithsonian Institution, State Hermitage Museum, The British Museum, The Prado Museum, The Metropolitan Museum, The Vatican Museum, The Uffizi Gallery and Rijksmuseum do.

The category of Information about museum employees is highly related to the curators and managers of museums. In regard of this category, museum employees share their experiences, views and opinions regularly with the followers. Le Louvre and The Vatican Museum have the least efforts on this category when compared to other museums.

Detailed information about artifacts/collections is a category that includes online display of the items exhibited at the museums to attract followers' interest at the pre- and post-visit stages. The results show that, all museums except The Vatican Museum post detailed information about artifacts and collections consistently.

Slogan is an impressive phrase that is used as a repetitive expression of an awareness or purpose and having a slogan for museums is highly important in terms of being original, distinctive, and competitive in marketing. Despite this, it is found out in this research that only Smithsonian Institution and The British Museum share their slogans on their own official Facebook accounts. 
Hashtag is a special term with the hash character \#, to form a tag about a special topic in social media accounts. A hashtag allows categorizing of similarly labeled messages or topics within the social media. It has been observed that most of the museums' accounts like Smithsonian Institution, Le Louvre Museum, State Hermitage Museum, The British Museum, The Metropolitan Museum, The Uffizi Gallery and Rijksmuseum have used hashtags in their 2014 posts.

Installation process of exhibitions arouses the excitement for the temporary exhibitions in the museums. Therefore, this category involves all the process of exhibition features, informs the followers in advance and prepares the audience about what to expect. In this context, this research shows that Smithsonian Institution, Le Louvre Museum, State Hermitage Museum, The British Museum, The Prado Museum, The Metropolitan Museum and Rijksmuseum have recognized the importance of this category.

Additional links shared on Facebook accounts of museums create and enhance the interaction with the followers. It is found out in the research that all official Facebook accounts present additional links to their own websites or some other websites for followers who seek for more information.

Researches, reports and projects of the museums involving special and outstanding posts exist on Smithsonian Institution, State Hermitage Museum, The British Museum, The Uffizi Gallery and Rijksmuseum's Facebook accounts among the museums that are subject to research.

Announcements include some essential messages such as; definite dates and themes of new exhibitions, symposiums, events, conferences and festivals organized within the museum. Almost all museums have announcements about their activities to provide up-to-date information and maintain followers' attention.

The category of Digital offers presents online experience to the followers through benefiting digitalism such as online exhibitions and online activities. It has been observed that all museums except Hermitage Museum have digital offers in their Facebook accounts.

Updates about museum includes essential information updates about museums' activity or event cancellations, opening/closing times, directions to the display rooms, full programs and various types of warnings. 
Videos, broadcasts, photographs, audio and online games are used to create a strong engagement with the followers of social media accounts. According to the content analysis of the Facebook accounts, it has been observed that the category of Posts of videos/broadcasts and Posts of photographs are supported by all museums whereas the category of Posts of audio was supported by only Le Louvre Museum and The Uffizi Gallery. On the other hand, Posts of online games is a distinctive category that is only supported by Le Louvre Museum.

Facebook accounts of museums have various types of tips and suggestions about its collections and artifacts. So, category of Tips/Suggestions is offered by only Smithsonian Institution, The Uffizi Gallery and Rijksmuseum.

In addition, for the inspiration of social media participation and interactive communication; Did you know that questions are raised to the followers on Facebook accounts. However, this category is only offered by Smithsonian Institution, Le Louvre Museum, The British Museum, The Metropolitan Museum and Rijksmuseum.

Invitations category involves direct invitations to certain events within the museum such as workshops, events, and courses. Le Louvre Museum, The Acropolis Museum, State Hermitage Museum, The British Museum, The Prado Museum, The Metropolitan Museum and Rijksmuseum are museums that post invitations on their Facebook account.

Educational posts assist the followers to improve their knowledge about the topics related to art and history. Smithsonian Institution, Le Louvre Museum, The British Museum, The Prado Museum, The Metropolitan Museum, The Uffizi Gallery and Rijksmuseum are the museums that support educational posts.

Suggestions and opinions of followers is another significant category which only Smithsonian Institution and Le Louvre Museum have on their official Facebook accounts.

Interactive talk which exists in only Le Louvre Museum provides opportunity for followers to ask inquiries to curators and museum directors online at a specified date and time.

Daily routine messages aim to create constant communication with the followers by daily messages such as "Good Morning", "Good 
Afternoon" and so forth. These posts with messages are usually accompanied by a museum's photograph to establish a strong relation.

Information about museums multimedia devices, Information about souvenirs in the Museum Shop, booking opportunities via account, Information about other facilities of museums, Donation opportunities and Information about facilities for disabled visitors are categories mostly similar to each other in regard of being information oriented to ease the followers' process of getting information.

The category of Engagement to current exhibitions is extremely different from others with allowing promotion of the new exhibition by updating account's cover picture.

The category of Competitions supported by only Rijksmuseum aims to inspire the followers and increase the participation level to the museums' official Facebook accounts.

\section{CONCLUSION}

Nowadays, museums are altering their steady structure to a more dynamic one and incorporating interactivity through digital developments to keep up with the era of digitalization. Thus, museums engage in digitalization to attain greater visibility by reaching a broader audience. In this context, museum directors seek for numerous means to take potential museum visitors' attention and comply with reality of virtual world. In this digital era, the need to adjust not only management functions but also promotion of museums has gained high importance. In order to reach the potential visitors, marketing of museums has gained importance particularly by the exploration of various new communication channels with the emphasis of social media. Through social media accounts, museums reach more people, create awareness, increase participation, inspire the potential museum visitors and establish values in general. Thereby, integration of museums to social networks is extremely essential.

As a marketing implication, to get admirable results from the social media presence of museums, the account should be managed appropriately by social media professionals with correct, current and upto-date information. Promotion of the museums through social media should pull both first time and repeat visitors with its vibrant and motivating messages about its activities and exhibitions. For instance, through posts about researches or projects, museums allow more qualified 
and substantial content to the followers who aim to acquire more scientific and academic knowledge in relation to exhibits. Since artifacts and collections with their special stories or myths are the main components of museums, detailed information should be provided to acknowledge the followers.

Additionally, technology offers many advantages such as interactive talk with the curators, which amazes art lovers in terms of an experience that is not even possible to encounter during the visit to the museum. An official social media account of a museum should also include a function for the followers to express suggestions and opinions about the improvement of museum exhibitions, related services or developing new ideas. This section will likely to build not only an interaction between the museum and the followers, but also the interaction among the followers. It is a fact that such interactive accounts take more attention and become more dynamic and interesting at the same time. Besides, social media accounts should also be used effectively in the promotion of museums through hashtags for instance. Hashtag usage in social media is a marketing effort to reach and expand the online viewers.

As a limitation, this study covers the examination of only ten international museums' Facebook accounts. Therefore, future research could involve a more comprehensive approach with examining different social media accounts of museums such as Twitter and Instagram. Findings of this study showed a strong bond between social media and museums in terms of marketing. Through this study, strategy on how to establish strong social media presence for museums is assessed and a framework was created accordingly. Indeed, it was confirmed that; some museums are more successful in benefiting from social media marketing advantages and in building affective and cognitive relation with the public in a consistent manner.

\section{REFERENCES}

Amato, F., Chianese, A., Mazzeo, A., Moscato, V., Picariello, A., \& Piccialli, F. (2013). The talking museum project. Procedia Computer Science, 21, 114-121.

Badalotti, E., De Biase, L., \& Greenaway, P. (2011). The Future Museum. Procedia Computer Science, 7, 114-116.

Bollo, A., \& Dal Pozzolo, L. (2005). Analysis of visitor behaviour inside the museum: An empirical study. In Proceedings of the 8th International Conference on Arts and Cultural Management, Montreal, pp.1-13. 
Chan, N. L., \& Guillet, B. D. (2011). Investigation of social media marketing: How does the hotel industry in Hong Kong perform in marketing on social media websites?. Journal of Travel \& Tourism Marketing, 28 (4), 345-368.

Cole, D. (2008). Museum marketing as a tool for survival and creativity: The mining museum perspective. Museum Management and Curatorship, 23 (2), 177-192.

Dindler, C., \& Iversen, O. S. (2009). Motivation in the museum: Mediating between everyday engagement and cultural heritage. Paper presented at the Nordes Conference. Oslo, Norway: 30 August - 01 September 2009.

Fletcher, A., \& Lee, M. J. (2012). Current social media uses and evaluations in American museums. Museum Management and Curatorship, 27 (5), 505-521.

Hausmann, A. (2012). The importance of word of mouth for museums: An analytical framework. International Journal of Arts Management, 14 (3), 32-43.

Hsu, Y. L. (2012). Facebook as international eMarketing strategy of Taiwan hotels. International Journal of Hospitality Management, 31 (3), 972-980.

Hume, M., \& Mills, M. (2011). Building the sustainable iMuseum: Is the virtual museum leaving our museums virtually empty? International Journal of Nonprofit and Voluntary Sector Marketing, 16 (3), 275-289.

Jeong, J. H., \& Lee, K. H. (2006). The physical environment in museums and its effects on visitors' satisfaction. Building and Environment, 41 (7), 963-969.

Kaplan, A. M., \& Haenlein, M. (2010). Users of the world, unite! The challenges and opportunities of Social Media. Business Horizons, 53 (1), 59-68.

Karagöl, A. (2014). The museum experience and social media. European Journal of Research on Education, 2 (1), 12-18.

Kelly, L. (2008). Museum 3.0: informal learning and social media. Paper presented at the 1st Social Media and Cultural Communication Conference. Sydney, Australia: 28-29 February 2008.

Kierzkowski, A., McQuade, S., Waitman, R., \& Zeisser, M. (1996). Marketing to the digital consumer. McKinsey Quarterly, 3, 5-21.

Kirezli, O. (2011). Museum marketing: Shift from traditional to experiential marketing. International Journal of Management Cases, 13 (4), 173-184.

Kotler, N. (2001). New ways of experiencing culture: The role of museums and marketing implications. Museum Management and Curatorship, 19 (4), 417-425.

Kotler, N., \& Kotler, P. (2000) Can museums be all things to all people?: Missions, goals, and marketing's role. Museum Management and Curatorship, 18 (3), 271-287.

Mancini, F., \& Carreras, C. (2010). Techno-society at the service of memory institutions: Web 2.0 in museums. Catalan Journal of Communication \& Cultural Studies, 2 (1), 5976.

Marty, P. F. (2007). Museum websites and museum visitors: Before and after the museum visit. Museum Management and Curatorship, 22 (4), 337-360.

McCall, V., \& Gray, C. (2014). Museums and the 'new museology': Theory, practice and organisational change. Museum Management and Curatorship, 29 (1), 19-35.

McLean, F. (1995). A marketing revolution in museums?. Journal of Marketing Management, 11 (6), 601-616.

Munar, A. M., \& Jacobsen, J. K. S. (2014). Motivations for sharing tourism experiences through social media. Tourism Management, 43, 46-54.

Padilla-Meléndez, A., \& del Águila-Obra, A. R. (2013). Web and social media usage by museums: Online value creation. International Journal of Information Management, 33 (5), 892-898.

Panero, J. (2012). Future tense, VII: what's a museum. New Criterion, 30 (7), 4-12. 
Pett, D. (2012). Use of social media within the British Museum and the museum sector. In C. Bonacchi (Ed.), Archaeology and Digital Communication: Towards Strategies of Public Engagement (pp.83-102). London: Archetype Publications.

Porter, M. (1998). Clusters and the New Economics of Competition. Harvard Business Review, 76 (6), 77-90.

Russo, A. (2011). Transformations in cultural communication: Social media, cultural exchange, and creative connections. Curator: The Museum Journal, 54 (3), 327-346.

Russo, A., Watkins, J., Kelly, L., \& Chan, S. (2008). Participatory communication with social media. Curator: The Museum Journal, 51 (1), 21-31.

Saravanakumar, M., \& Suganthalakshmi, T. (2012). Social media marketing. Life Science Journal, 9 (4), 4444-4451.

Scott, S. V., \& Orlikowski, W. J. (2012). Reconfiguring relations of accountability: Materialization of social media in the travel sector. Accounting, Organizations and Society, 37 (1), 26-40.

Sparks, B. A., Perkins, H. E., \& Buckley, R. (2013). Online travel reviews as persuasive communication: The effects of content type, source, and certification logos on consumer behavior. Tourism Management, 39, 1-9.

Stylianou-Lambert, T. (2011). Gazing from home: Cultural tourism and art museums. Annals of Tourism Research, 38 (2), 403-421.

Styliani, S., Fotis, L., Kostas, K., \& Petros, P. (2009). Virtual museums, a survey and some issues for consideration. Journal of Cultural Heritage, 10 (4), 520-528.

Waltl, C. (2006). Museums for visitors: audience development-a crucial role for successful museum management strategies. Paper presented at the Intercom. Taipei, Taiwan: 2-4 November 2006.

Weilenmann, A., Hillman, T., \& Jungselius, B. (2013). Instagram at the museum: Communicating the museum experience through social photo sharing. In Proceedings of the SIGCHI Conference on Human Factors in Computing Systems, pp.1843-1852.

Xiang, Z., \& Gretzel, U. (2010). Role of social media in online travel information search. Tourism Management, 3 (2), 179-188.

Yeh, J., \& Lin, C. (2005). Museum marketing and strategy: Directors' perception and belief. Journal of the American Academy of Business, 6 (2), 279-284.

Zeng, B., \& Gerritsen, R. (2014). What do we know about social media in tourism? A review. Tourism Management Perspectives, 10, 27-36.

Zhou, L., \& Wang, T. (2014). Social media: A new vehicle for city marketing in China. Cities, 37, 27-32. 